\title{
Farklı Sosyal Kırılganlık Düzeyine Sahip Mahalle Muhtarlarının Gözünden Covid-19 Salgın Deneyimi: İstanbul İli Örneği
}

\author{
Gülçin CON WRIGH' ${ }^{1}$ \\ ORCID: 0000-0001-7196-151X
}

Kezban ÇELİK ${ }^{2}$

ORCID: 0000-0003-0234-9006

DOI: $10.54752 /$ ct.1060807

Öz: Bu makale, Covid-19 pandemisinin mahalle düzeyinde nasıl deneyimlendiğini muhtarların gözünden irdelemektedir. Çalışmada, pandemi deneyiminin ve pandeminin yerel yönetişiminin, farklı sosyal kırılganlıklara sahip mahallelerde farklılaşan ve benzeşen yönlerinin, muhtarların gözünden anlaşılması hedeflenmektedir. Makalede kullanılan veriler, İstanbul ilinin farklı sosyal kırılganlık seviyesine sahip 4 ilçesinin farklı mahallelerinde görev yapan 20 muhtar ile çevrimiçi uygulamalar üzerinden gerçekleştirilmiş yarı-yapılandırılmış görüşmelere dayanmaktadır. Çalışmada gerçekleştirilen analiz sonucunda, mahallenin sosyal kırılganlık düzeyi ile pandemi deneyimi arasında ilişki olduğu ve mahalle muhtarlarının pandemiyi yönetmeye ilişkin çabaları ve mahallenin sosyal kırılganlık düzeyinin ilişkili olduğu bulgulanmıştır. Buna göre, kır1lganlık düzeyi daha düşük mahallelerde pandemi deneyim ve yönetişiminde yaşanan sıkıntıların, mahallelerin demografik yapısıyla ilgili olduğu, kırılganlığı daha yüksek olan mahallelerde hem maddi hem de pandemi kurallarına uyumla ilgili sorunların baş gösterdiği ortaya çıkmıştır. Çalışma, mahallelerin pandemi deneyiminin sosyal kırılganlık düzeyine göre biçimlendiğini ve pandemi yönetiminin de mahallenin yapısal ve işlevsel özelliklerine uygun bir biçimde gerçekleștirilmesi gerektiğini ortaya koymuştur. Araştırmanın sonuçları, gelecekte yaşanabilecek benzer pandemilerin yönetilmesine ve ayrıca, kurumların müdahale yöntemlerini etkin bir şekilde uygulamalarına destek sağlayabilecek bazı ipuçları içermektedir.

Anahtar kelimeler: Covid-19 pandemisi, mahalle muhtarları, farklı sosyal kırılganlık düzeyine sahip mahalle, pandeminin yerel yönetişimi

${ }^{1}$ Dr. Öğr. Üyesi, TED Üniversitesi, Sosyoloji Bölümü

2 Prof. Dr. TED Üniversitesi, Sosyoloji Bölümü

Makale Geliș Tarihi: 03.06.2021 - Makale Kabul Tarihi: 08.12.2021

Çalışma ve Toplum, 2022/1 
COVID-19 Pandemic Experiences from the Perspective of Mukhtars of Neighborhoods with Differing Levels of Vulnerability: The Case of Istanbul

Abstract: This paper examines how Covid-19 pandemic is experienced at the neighborhood level from the mukhtars' perspective. It aims to reveal the similarities and differences in experiences and local governance of the pandemic in neighborhoods depending on their level of social vulnerability. The data come from semi-structured interviews conducted online with 20 mukhtars from different neighborhoods in 4 municipalities of Istanbul with differing levels of social vulnerability. The findings show that there is a relation between the social vulnerability level of the neighborhood and its pandemic experiences as well as the mukhtar's efforts related to pandemic governance. In neighborhoods with lower levels of social vulnerability, the main issues with the pandemic experiences and management were related to the demographic composition. In those with higher levels of social vulnerability, in addition to financial problems, issues arose regarding compliance with pandemic regulations. This paper elucidates that pandemic experiences are shaped by neighborhoods' level of social vulnerability and that there is a need for pandemic governance which takes into account the structural and functional characteristics of neighborhoods. It provides some insights which would benefit the institutions in their management of any future pandemics by serving as a guide for more efficient and effective intervention measures.

Keywords: Covid-19 pandemic, neighborhood mukhtars, neighborhoods with different levels of social vulnerability, local governance of the pandemic

\section{Giriş}

Yeni Koronavirüs Hastalığ1 (Covid-19) ortaya çıkışından kısa bir süre sonra tüm ülkelerde yayılmış ve Dünya Sağlık Örgütü tarafindan pandemi olarak ilan edilmiştir. Türkiye'de de kısa süre içinde hayatı derinden etkileyen bu küresel pandemi, uzun vadede de toplumun yapısı ve gündelik hayatın işleyişinde kalıcı etkiler yaratmıştır ve yaratmaya devam etmektedir. Virüsün yayılmasını durdurmak amacıyla alınan önlemler uyarınca, evlerde izolasyon, sosyal mesafe, maske ve hijyen gibi tedbirlere her ülkenin kendi toplumsal yapısı ve kültürüne göre tepki verdiği görülmüştür. Ayrıca, bu tür kısıtlamaların uygulanmasında eşitsiz deneyimler yaşandığ gözlemlenmiştir. Toplumlarda var olan eşitsizliklerin, halk sağlığında yarattığı eşitsizliklerle bağlantısı vurgulanarak Covid-19 salgını için "sosyal hastalık" kavramı da kullanılmıştır (Çaman ve Karabey, 2020: 4). 
Pandeminin henüz başlangıcındaki tartışmalarda, yeni korona virüsünün herkesi eşit şekilde etkileyeceği varsayılmıştır; ancak, kısa zaman içinde hem pandeminin deneyimlenme biçimlerinin hem de çeşitli grupların bu süreçte uygulanan önlemlere uyum becerilerinin pandemi öncesindeki toplumsal eşitsizliklere göre şekillendiği ortaya çıkmıştır (Estrala vd., 2020; Smith ve Judd, 2020). Bu doğrultuda, farklı grupların pandemiye ve beraberinde gelen süreçteki uygulamalara karşı tepkilerindeki farklılıkların, toplumun yapısına işlemiş çeşitli sosyal kırılganlıklarla örtüştüğü görülmektedir.

Sosyal bilimciler, pandemilere ilişkin önceki çalışmaların sonuçlarını, pandeminin yayılım alanlarını ve toplumun farklı kesimlerindeki etkilerini incelemiş ve benzer bulgulara ulaşmışlardır (Craddock, 2000; Kalipeni, 2000; McLafferty, 2010). Covid-19 pandemi sürecinde de toplumun çeşitli kesimlerinin bireysel izolasyon ve sosyal mesafe gibi önlemleri kendi hayatlarnnda uygulayabilmelerinin mümkün olmadığı ve dolayısıyla, riske daha çok maruz kaldıkları görülmüştür. Düşük gelirli sınıfların yaşadıkları mahallelerdeki nüfus yoğunluğuna ek olarak, hane içindeki birey sayısının yüksek olması, evden çalışmaya uygun olmayan işlerde çalıştıkları ve ekonomik durumlarından ötürü risk alıp çalışmaya devam etmek zorunda kalmaları gibi unsurlar, bu grupların virüse yakalanma ihtimallerini arttırmaktadır (Ro, 2020).

Pandeminin deneyimlenme biçimlerinin mekâna nasıl yansıdığının anlaşılabilmesi için İstanbul örneği, sıklıkla, ülkedeki diğer iller ile kıyaslanmaktadır. Türkiye'nin 'küresel kenti' olarak anılan İstanbul'da yaşayanların pandemiyi deneyimleme biçimleri ve pandemi sırasında yaşadıklarının yanı sıra, burada gözlemlenen sosyal, ekonomik ve psikolojik değişimler, ülkenin geri kalanından önemli ölçüde farklllık arz etmektedir (Sayin ve Bozkurt, 2020). İstanbul'daki deneyimin farklı olmasının başlıca sebeplerinden biri; küresel şehirlerin hastalığın yayılması anlamında bir ağ görevi görmesiyle bağlantılidır. Ayrıca, nüfus yoğunluğu, İstanbul gibi küresel şehirleri virüsün yayılımını önlemek adına gerekli sosyal mesafeyi sağlamak konusunda da zora sokmaktadır. Pandemi tedbirlerine uyum seviyesi ve bu tedbirlerin uygulanma başarısı da küresel şehirlerin kendi sınırları içerisinde farklilık arz etmektedir. Örneğin, bu şehirlerde yaşayan her bir birey için pandemiden kaynaklanan ekonomik kayıplar farklı ölçektedir. Akyıldız’n (2020) Türkiye'nin genelini kapsayan çalışmasında, İstanbul'da ikamet eden katılımcıların \%51,2'sinin gelirlerinin azaldığı belirtilirken, İstanbul dışında ikamet eden katılımcılar gelirlerinde bir değişme olmadığını ifade etmiştir. Dolayısıyla, kimi kesimlerin pandemiye karşı ekonomik anlamda diğer kesimlere kıyasla daha kırılgan olduğu ortaya çıkmıştır.

$\mathrm{Bu}$ makale dört bölümden oluşmaktadır: İlk bölüm, mahalle ve mahalle muhtarlığına ilişkin güncel duruma; ikinci bölüm, sosyal kırılganlık ve mekâna yansıyan eşitsizliklere; üçüncü bölüm, araştırmanın yöntemine; son bölüm ise bulgular ve bulguların işaret ettiği sonuçlara odaklanmaktadır. 


\section{Araştırmanın Arka Planı}

\section{Mahalle ve Mahalle Muhtarlığı}

$\mathrm{Bu}$ çalışma, mahalle ve mahalle muhtarlığını birlikte değerlendirmeyi amaçlamaktadır. Mahalle, hem bir mekâna hem de mekânda yaşayanlara gönderme yapmakta olup bu nitelikleri ile sosyolojik bir birim olma niteliği taşımaktadır. Mahalle, 2005 yilında yürürlüğe giren 5393 sayılı Belediye Kanunu'nun üçüncü maddesinde 'Belediye sinırları içinde, ihtiyaç ve öncelikleri benzer özellikler gösteren ve sakinleri arasında komşuluk ilişkisi bulunan idarî birim" şeklinde tanımlanmaktadır. Mahalle muhtarlı̆̆ı ise bu mekânsal birimde yaşayanların temsiline gönderme yaparak idari bir kategori olma özelliği taşımaktadır (Palabiyık ve Atak, 2002: 2). Öte yandan, hem mahalle hem de mahallenin idari temsili, toplumsal boyutta meydana gelen değişimler ile birlikte dönüşmektedir. Bu bağlamda, ne mahalle ne de idari mekanizma için genel geçer bir tanım yapmak tam olarak mümkün olmamaktadır. Nihayetinde, mahalle tanımlamaları, mahallenin yerleştiği üst birimde gerçekleşen ve buna bağlı olarak hem işlevselliği hem de yönetselliğinde meydana gelen değişimlerden etkilenmektedir (Yalçındağ, 1998: 50).

Türkiye özelinde mahalleye yönelik araştırmalara bakıldığında, çalışmaların büyük çoğunluğunun sosyolojik nitelikleri ile mahallenin dönüşümünü incelediği ve bu bağlamda, bu dönüşümlerin mahalle sakinlerine nasil yansıdı̆̆ına odaklanıldığı görülmektedir (Ayataç ve Turan, 2020: 33). Toplumsal değişimin mahalleye nasil yansıdığ1 ve mahallenin işlevsel özelliklerini nasıl dönüştürdüğü üzerine yapılan çalışmaların, bu konuyu genellikle büyük toplumsal dönemselleştirmeler üzerinden ele aldığ1 söylenebilir. Bu kapsamda Eren (2017), Türkiye özelinde mahallenin geçirdiği değişimleri simgeleyen üçlü dönemselleştirme üzerinden mahalleyi tanımlamaktadır: geleneksel, modern ve modern sonrası mahalle. Bu üçlü dönemselleştirmeye göre, Osmanlı dönemindeki mahalle "geleneksel"; sanayileşmeyle beraber başlayan dönemdeki mahalle ise "modern" olarak nitelendirilmektedir. Son olarak, küreselleşmenin etkisiyle doğan modern sonrası dönemi karakterize eden "modern sonrası mahalle" tanımı kullanılmaktadır. Dönemselleştirme, her dönemde mahallenin geçirdiği dönüşüm ve değişimler dikkate alınarak yapılmakta ve bu dönüşümlerin, mahalle sakinlerinin kendi aralarındaki ilişkileri dönüştürdüğü varsayımına dayanmaktadır. Keyder (2009) günümüzde yaşanan ve mahallenin dönüşümüne neden olan değişimi "bölünme" ile açıklamaktadır. Küresel sisteme ayak uyduran kent parçasılyla küresel sitemden kopmuş kent parçasının yan yana gözlemlenebilmesi, bu bölünmüşlügü ifade etmektedir (Ayataç ve Turan, 2020).

Dönüşümlere bağlı olarak mahallenin örgütlenmesine ilişkin yönetsel mekanizmanın da değişim gösterdiği görülmektedir. Geleneksel mahalleyi temsil eden Osmanlı dönemi mahallesinin muhtarlık temsili ile örgütlenmiş olduğu ve bu mekanizmanın, Cumhuriyet dönemine de aktarılmış önemli bir yönetsel birim olduğu görülmektedir (Güneş, 2009: 113). Bu düzen, hukuki statüsünde bir değişiklik yapilmadan 1934 yllına kadar devam etmiştir (Şahin ve Asarkaya, 2019: 28). Söz konusu yıl itibariyle ise, belediye oluşumunun tamamlandiğı düşünülerek mahalle 
muhtarlığ1 bir yönetsel birim olarak kaldırılmış ve görevleri belediyelere ve merkezî idareye devredilmiştir. Ancak, devir işlemini takip eden 10 ylllk deneyim, mahalle muhtarlığına yeniden gereksinim olduğunu göstermiş ve 1944 yllında mahalle muhtarlığ1 yeniden kurulmuştur (Arıkboğa, 1999: 112; Eryılmaz, 1988: 474).

Mahalle muhtarlığı, yeniden tesis edildiği 1944 yllından günümüze kadar varllğını sürdüren bir birim olmuştur. Diğer yandan, mahallenin değişim ve dönüşümüne paralel bir şekilde, mahalle muhtarlığının da dönüştüğü görülmektedir. Söz konusu dönüşüme ilişkin önemli değişiklikler, bilhassa, 2005 yllında ortaya çıkmıştır. 2005 tarihli 5393 sayılı Belediye Kanunu'nda mahalle ve mahalle muhtarlığıla ilgili bazı yeniliklerin yapıldığı düzenleme iki önemli değişikliğe işaret etmektedir (Akman, 2018: 517). İlk düzenleme, mahallenin nasıl kurulacağını; ikinci düzenleme ise mahalle muhtarının görevini tanımlamıştır. $\mathrm{Bu}$ düzenlemeye göre "belediye sınırları içinde mahalle kurulması, kaldırılması, birleştirilmesi, bölünmesi, adlarıla sınırlarının tespiti ve değiştirilmesi, belediye meclisinin kararı ve kaymakamın görüşü üzerine valinin onay1 ile olacağı" belirtilmiştir. Mahalle muhtarının görevi ise "mahalle sakinlerinin gönüllü katılımıyla ortak ihtiyaçları belirlemek, mahallenin yaşam kalitesini geliştirmek, belediye ve diğer kamu kurum ve kuruluşlarılyla ilişkilerini yürütmek, mahalle ile ilgili konularda görüss bildirmek, diğer kurumlarla iş birliği yapmak ve kanunlarla verilen diğer görevleri yapmak" olarak tanımlanmıştır.

2012 yılına gelindiğinde, Türkiye'deki büyük şehir sayısını arttıran 6360 sayılı Kanun'un kabulü ile birlikte, mahalle ve mahalle muhtarlığının yapısında bir kez daha önemli değişimler meydana gelmiştir. Söz konusu kanunla 14 ilde büyükşehir kurulmuş ve böylece, Türkiye'deki büyükşehir sayıs1 30'a yükseltilmiştir. Aynı zamanda, büyükşehir belediye sınırları "il mülki sınırı" olarak belirlenmiştir. Bu durumda, büyükşehir belediyesi hâline getirilen illerdeki bütün köylerin tüzel kişilik nitelikleri kaldırllmış ve bunlar, mahalle statüsüne dönüştürülmüştür. 6360 sayılı Kanunun uygulanmasindan sonra mahalle olan 16.120 köy ile birlikte (Göküş ve Alptürker, 2016: 68) hem mahalle sayısı artmış hem de sonradan oluşturulan mahalleler, mahalle kimliklerinin farklılaşmasına neden olmuştur (Kavruk, 2018: 83). İçişleri Bakanlığı'nın (2020) verilerine göre 2020 yllı itibariyle Türkiye'de büyükşehir, il, ilçe, belde belediyeleri dâhil toplam 1389 belediye ve 32.164 mahalle bulunmaktadır. Köyler dâhil edilerek hesaplandığında Türkiye'deki toplam muhtarlık sayıs1 50.456'y1 bulmaktadır (Bulut, 2020).

Mahalle muhtarlığını yönetsel bir birim olarak değerlendirmek açısından 2015 'in de önemli bir yll olduğu söylenebilir. Mahalle muhtarllğı, uzun ylllar yerel ile merkezî yönetim arasında aracı bir birim olarak ve çoğunlukla partisiz siyasetin yapıldığ1 yerinden yönetimin en önemli arac1 olarak görülmüştür. Ancak, 2015 yllında Cumhurbaşkanı Erdoğan yaklaşı 50 bin muhtar ile kısa aralıklarla toplantılar yapmış ve bu toplantılar sonucunda muhtar taleplerine ilişkin bir genelge yayınlanmıştır. Mahalli İdareler Genel Müdürlüğü tarafından yayımlanmış olan bu yeni genelgenin önemi "muhtarlıkların yerel kattlım ve demokrasi ile bağı ve 
önem’lerine (Özkan Erdoğan, 2016: 7) yaptı̆̆1 vurgudadır. Bu gelişmelere ek olarak, 19 Ekim, Muhtarlar Günü olarak ilan edilmiş ve elektronik bir sistem olan "Muhtar Bilgi Sistemi" de bu toplantılarda tanıtılmıştır. Tüm bu önemli değişimlere rağmen mekânsal bir birim olarak mahalleler, hâlen yerel yönetim teşkilatı içerisinde yer almamakta ve bu özelliği ile de tüzel bir kişiliğe sahip olmamaktadır. Muhtarlar kamu tüzel kişiliğinin olmaması nedeni ile kendi başına karar alamamakta, kendine ait bir bütçesi olmadığ için de harcama yapamamaktadır (Özkan Erdoğan, 2016: 135). Bir yandan yönetsel düzenlemelerin sonucunda ortaya çıkan eksiklikler, diğer yandan mahallenin sosyolojik dönüşümüne bağlı olarak mahalle muhtarlarının işlevlerinin, fonksiyonlarının ve kapasitelerinin zayıflaması, mahalle muhtarlı̆̆ını, merkezin yereldeki işlerini yürüten aracı bir kuruma dönüştürmektedir (Akman, 2018; Arıkboğa, 1999: 167; Bulut, 2001: 33-34; Bulut ve Kara, 2011: 179; Kavruk, 2018: 93-94).

Öte yandan, mahalle muhtarları hâlen partisiz siyaset yapabilen, mahalleli tarafından seçimle işbaşına gelen ve yaptıkları görev nedeni ile genel bütçeden aylık ödemesi yapılan merkezî yönetimin en küçük birimi olma özelliğini sürdürmektedir. Ancak, muhtarlar kendi toplulukları tarafından seçilmiş olsalar da diğer seçilmiş yerel yöneticilerin sahip oldukları idari ve mali imkânlardan yoksundurlar (Güneş, 2009; Palabiyık ve Atak, 2002). Bu durum göz önünde bulundurulduğunda, mahalle muhtarllğının günümüz dünyasında neye karşılık geldiği ve mahalle muhtarlarının kendi işlevselliklerini nasıl algıladıklarını anlamak önem kazanmaktadır.

Tüm sinırll1ıklara rağmen, muhtarların yerel düzeyde üstlenmiş oldukları arac1 rolleri önemini korumaktadır (Bulut ve Akın, 2020). Özellikle, afete karş1 hazırlıklı olma anlamında yerel yönetimlere daha fazla görev düştüğü, dolayısıyla mahalle muhtarlığının topluluk temelli afet yönetişiminde merkezî bir konuma sahip olduğu anlaşılmaktadır (Çakı ve Özbayram, 2020). Nitekim pandemi sürecinde muhtarlara çok önemli kimi görevler düştüğü, muhtarların "devlet ile vatandaşlar arasında köprü kurduğu” bir kez daha vurgulanmıştır (Altunöz, 2020).

\section{Afetler ve Sosyal Kırılganlık}

Bu çalışmada Covid-19 pandemisi bir afet türü olarak ele alınmakta ve bu pandeminin farklı sosyal kırılganlık düzeylerindeki mekânlarda nasıl deneyimlendiği incelenmektedir. Buna bağlı olarak, çalışmanın temel teorik çerçevesi de sosyal kırılganlık kavramı ve literatürü etrafında şekillenmektedir.

Sosyal bilimler literatüründe, afetlere karşı hazırlıklı olabilme ve afetlerin sosyal etkileriyle mücadele edebilme kabiliyeti "sosyal kırlganlık" terimiyle tanımlanmaktadır (Cuttler ve Finch, 2008). Bu bağlamda, afetlere karşı sosyal anlamda savunmasız olma durumuna karşlık gelen sosyal kırılganlık (Cannon vd., 2003), toplumsal düzeyde, afetlerin etkilerinden daha az zarar görebilme ve afetlerin sonrasında da daha hızlı bir şekilde iyileşebilme seviyesine dair fikir sunmaktadır. Toplumların yapıları gereği, sosyal kırılganlıkları birbirlerinden farklılık göstermektedir. Nitekim bazı toplumlar diğerlerine kıyasla afetlere karşı daha az 
hassas ya da daha fazla hazırlıklı olabilmektedir. Bu farklılıkların arkasındaki en önemli faktörlerden birisi de toplumu oluşturan grupların özellikleridir. Toplumdaki çocuklar, yaşllar ve engelliler gibi risk grubunda sayllan insanlar ve göçmenler ve kadınlar gibi çeşitli yapısal eşitsizliklere maruz kalma ihtimalleri diğerlerinden daha yüksek olan bazı grupların yoğun olduğu toplumların, afetlere karşı sosyal kırlganlıklarının da görece daha yüksek olduğu bilinmektedir (Bankoff, 2002).

Sosyal kırılganlık, afetlerden doğan bir riskin çıktısı olmaktan ziyade, afet öncesi eşitsizliklerle biçimlenen riskle başa çıkma ve riske hazırlıklı olma durumu olarak ele alınmalıdır. Afetin doğurduğu riskten önceki koşulları belirleyen faktörler; kişilerin çeşitli toplumsal özellikleri üzerinden riske karşı dirençleri, tepkileri ve riskle başa çıkma yetilerini eşitsiz bir biçimde etkileyen unsurlardır (Cuttler, 1996). Bir yandan, kişinin yaşı, cinsiyeti, eğitim durumu gibi bireysel özellikleri riske karşı tepkisini belirlerken, diğer yandan da yoksulluk ve engellilik gibi toplumsal konumları, bu kişilerin, çeşitli krizlere daha sıł maruz kalmalarına ve ayrıca riskle başa çıkmada kullanabilecekleri kaynaklarını sınırlandırmaktadır (Holzmann ve Jørgensen, 2001).

Farklı yapısal eksikliklerin pandemi koşullarında kırılganlık düzeyini etkilemesi; kırılganlı̆̆ın, pandemi sürecinde yeniden tanımlanmasını ve buna sebep olan faktörlerin en baştan incelenmesi ihtiyacını ortaya koymuştur (Stephenson vd., 2013). Örneğin, pandemi karşısında kırılganlı̆̆1 ülke çapında azaltabilecek etkili önlemler olarak "hazırlıklı olma" ve "etkili politika" ön plana çıkmaktadır. Ancak, hanelerin ve bireylerin sosyo-ekonomik statüleri ve kırılganlık düzeylerine orantılı biçimde "hazırlıklı olma" seviyeleri de farklılık göstermektedir (Sands vd., 2016). Pandemi yönetişimi açısından, bazı kesimlerin yeterince hazır olmaması ya da tedbirleri uygulayamaması farklı sebeplere bağlanmaktadır. Genel itibariyle sosyal kırılganlık yoksulluk ile ilişkilendirilen bir konudur. Bununla birlikte, Brezilya'da gerçekleştirilen bir çalışmada, pandemi sırasında sağlığın sosyal belirleyici faktörleri arasındaki etkileşimin yoksulluktan daha fazla önemli olduğu gözlemlenmiştir (de Moraes Silva ve Mont'Alverne, 2020). Bu çalışmada, finansal güvencesizliği olan, okuryazarlık seviyesi düşük olan, çeşitli bağımlılıklarla mücadele eden, bağımsız yaşama ve günlük temel ihtiyaçları karşılaması mümkün olmayan grupların sosyal kırılganlığını belirleyen en önemli faktörün "kaynaklara kısıtlı erişim”leri olduğu tespit edilmiştir. Kırılgan mahallelerde en büyük endişenin ekonomiye ve istihdama dair olduğu, ancak, kaynaklara erişimin de istihdama bağlı olması sebebiyle, kırılganlığ1 arttıran faktörün sadece ekonomik olmadığ ortaya konulmuştur.

Pandemi sürecinde, diğer afetlere kıyasla farklı bir tedbir olarak yapılan "evde izolasyon" uygulaması, kırllganlığı ve dayanıklılı̆̆ da mekân ekseninde ele almayı gerekli kılmıştır. Bu gereklilik, mahallenin, pandemiye karşı sosyal dayanıklıllğı üzerine odaklanan bazı tartışmaları da beraberinde getirmiştir (Ayataç ve Turan, 2020). Bu bağlamda, mahallelerin fiziksel mekânlar olarak geçirdikleri değişimlerin, mahalle sakinlerinin hem kırllganlık hem de dayanıklılık seviyelerini etkileyeceği kabul edilmektedir. Dolayısıyla yaşanan ya da yaşanması muhtemel bazı beklenmedik 
değişimlere karşı başa çıkabilme yetisi geliştirmesi durumunda, bir mahalle, sosyal dayanıklı olarak kabul edilebilir. Covid-19 pandemisi, hem bireylerin hem de toplulukların kırılganlıklarını temel olarak sağlık üzerinden belirleyen ve biçimlendiren bir afet türüdür. Bu bağlamda, bir mahallede sağlık hizmetlerine erişim, mahalle sakinleri arasındaki dayanışma ve üretilen çeşitli pratiklerle pandemiye daha hazırlıklı olma gibi etkenler önem taşımaktadır. Bu durum da sosyal kırılganlık ve sosyal dayanaklılık üzerine yeni tartışmaları gerekli kılmaktadır. Bu durumun farkında olarak, bu çalısmada, farklı sosyal kırılganlık düzeyine sahip hanelerin mekânda kümelendiği yerler olan mahallelerin Covid-19 pandemisini deneyimleme biçimleri muhtarlar ile yapılan derinlemesine görüşmelerden derlenmiştir.

\section{Araştırmanın Yöntemi}

Bu çalısmada, 2020 yllında Tübitak desteğiyle gerçekleştirilen "Farklı Sosyal Kırılganlık Düzeyine Sahip Hanelerin Covid-19 Salgınını Deneyimleme Biçimleri ve Yakın Geleceğe İlişkin Beklentileri: İstanbul İli Örneğı” başlıklı araştırmanın verileri kullanılmaktadır. Araştırma İstanbul ilinde gerçekleştirilmiştir. Bunun iki temel gerekçesi vardır: Bunlardan ilki; İstanbul ilinin Covid-19 pandemisinin Türkiye'de en yoğun yaşandığı il olması ve hatta Sağlık Bakanı Koca'nın Nisan 2020'deki basın açıklamasında “İstanbul Türkiye'nin Wuhan'1 olmuştur” şeklindeki tanımlamasıdır. İkinci neden ise, bu araştırmanın, proje ekibinin daha önce 20172018 ylllarında İstanbul'da gerçekleştirdiği temsilî bir örnekleme dayanan araştırmada geliştirilen sosyal kıılganlık sınıflandırmasına dayanıyor olmasıdır.

Bu çalışma için, farklı sosyal kırılganlık düzeyine sahip 4 ilçeye (Sancaktepe, Bağcılar, Kadıköy, Beylikdüzü) bağlı mahallelerin muhtarları tek tek aranmış ve sonucunda 20 mahallenin muhtarı görüşmeye katılmayı kabul etmisstir. Muhtarlarıyla görüşülen mahallelerin sosyal kırılganlık düzeyleri, 2018 yllında gerçekleştirilen araştırmadan elde edilen verilere dayanan kırilganlık skorlarına göre hesaplanmıştır. $\mathrm{Bu}$ hesaplamaya göre, ortalama kirılganlık puanı; 0-43.99 arasında olanlar kirilgan olmayan, 44-49.99 arasında olanlar orta-alt kırllgan, 50-59.99 arasinda olanlar orta-üst kırılgan ve 60-100 arasında olanlar da kırılgan mahalleler olarak belirlenmiştir. Bu çalışmanın kapsamında 3 kırılgan, 9 orta-üst kırilgan, 5 orta-alt kırılgan ve 3 kırilgan olmayan kategorisine giren mahallenin muhtarryla görüşülmüştür.

$\mathrm{Bu}$ araştırmanın örneklemini Bağcılar ilçesinden 8, Beylikdüzü ilçesinden 2, Kadıköy ilçesinden 6 ve Sancaktape ilçesinden 4 muhtar oluşturmaktadır. Bu muhtarların sadece 4'ü kadın, 16'sı ise erkektir. Görüşülen muhtarların 8'i muhtarlıklarının 1. döneminde, 4'ü 2. döneminde, 6's1 3. döneminde, 1'i 4. döneminde ve 1'i de 6. döneminde olduklarını belirtmişlerdir. Aynı şekilde, eğitim seviyeleri açısından da mahalle muhtarları arasında çeşitlilik söz konusudur. Nitekim üniversite mezunu muhtar sayısı 4'te kalırken, 2 muhtar Açık Öğretim Fakültesi'nde eğitimine devam ettiğini belirtmiştir. Geriye kalan muhtarların çoğu lise ve lise altı eğitim düzeyindedir. Araştırmaya katılan muhtarlara dair demografik bilgi, Tablo 1'de sunulmuştur. 
Tablo 1. Görüşülen Muhtarların Demografik Özellikleri

\begin{tabular}{|c|c|c|c|}
\hline $\begin{array}{l}\text { Mahallenin Sosyal Kırılganlık } \\
\text { Seviyesi/Bağlı Olduğu İlçe }\end{array}$ & $\begin{array}{l}\text { Muhtarlık } \\
\text { Dönemi }\end{array}$ & Cinsiyet & Ĕ̆itim Seviyesi \\
\hline Orta-alt kırılgan mahalle/Kadıköy & 2.Dönem & Erkek & Lise Mezunu \\
\hline Orta-alt kırılgan mahalle/Kadıköy & 1.Dönem & Kadin & Üniversite Mezunu \\
\hline Orta-alt kırılgan mahalle/Kadıköy & 1.Dönem & Kadın & Üniversite Mezunu \\
\hline Kırılgan olmayan mahalle/Kadıköy & 6.Dönem & Erkek & Üniversite Mezunu \\
\hline Kırılgan olmayan mahalle/Kadıköy & 3.Dönem & Kadin & Üniversite Mezunu \\
\hline Orta-alt kırılgan mahalle/Kadıköy & 3.Dönem & Erkek & $\begin{array}{l}\text { Lise Dengi } \\
\text { Mezunu }\end{array}$ \\
\hline Kirilgan mahalle/Sancaktepe & 3.Dönem & Kadin & Lise Mezunu* \\
\hline Kirilgan mahalle/Sancaktepe & 1.Dönem & Erkek & Lise Mezunu* \\
\hline Kirilgan mahalle/Sancaktepe & 1.Dönem & Erkek & Lise Mezunu \\
\hline Orta-üst kırılgan mahalle/Sancaktepe & 1.Dönem & Erkek & Lise Mezunu \\
\hline Orta-üst kırılgan mahalle/Bağcılar & 3.Dönem & Erkek & (belirtilmedi) \\
\hline Orta-üst kırılgan mahalle/Bağcılar & 4.Dönem & Erkek & Lise Mezunu \\
\hline Orta-üst kırılgan mahalle/Bağcılar & 1.Dönem & Erkek & (belirtilmedi) \\
\hline Orta-üst kırılgan mahalle/Bağcılar & 2.Dönem & Erkek & Lise Mezunu \\
\hline Orta-üst kırılgan mahalle/Bağcılar & 2.Dönem & Erkek & (belirtilmedi) \\
\hline Orta-üst kırılgan mahalle/Bağcılar & 2.Dönem & Erkek & (belirtilmedi) \\
\hline Orta-üst kırılgan mahalle/Bağcılar & 1.Dönem & Erkek & Lise Mezunu \\
\hline Orta-üst kırılgan mahalle/Bağcılar & 3.Dönem & Erkek & Ortaokul Mezunu \\
\hline Orta-alt kırılgan mahalle/Beylikdüzü & 3.Dönem & Erkek & Ortaokul Mezunu \\
\hline Kırılgan olmayan mahalle/Beylikdüzü & 1.Dönem & Erkek & (belirtilmedi) \\
\hline
\end{tabular}

* Açı Öğretim Fakültesi'nde eğitimine devam ediyor 
Araştırmaya katılan 20 muhtar ile Ekim ve Kasım aylarında "yarı yapılandırılmış görüşme”ler gerçekleştirilmiştir. Bu araştırma, 18 Haziran 2020 tarihli ve 27535802-050.03.04 say11 Etik Kurul Karar1 ile etik kurallarına uygun olarak onaylanmıştır. Görüşmeler Zoom ya da Whatsapp uygulamaları üzerinden çevrimiçi bir şekilde gerçekleştirilmiş ve önceden hazırlanmış olan görüşme formu çerçevesinde yürütülmüştür. Görüşmeler esnasında, muhtarlardan, görev yaptıkları mahallenin Covid-19 pandemisini deneyimleme biçimleri, mahalle sakinlerinin pandemi tedbirlerine uyumları ve kendilerinin pandemi yönetişimindeki rolleri üzerine görüşleri alınmıştır. Yapılan görüşmeler, muhtarların izni alınarak kayıt edilmiş ve görüşme sonrası çözümlenmiştir.

Çözümlenmiş görüşmeler tematik analiz tekniği kullanılarak değerlendirilmiştir. Değerlendirme yapıllrken, muhtarlarla yapılan görüşmeler sırasında üzerinde durulan üç tema (mahallenin özellikleri, pandemi deneyimi ve pandemi yönetişimi) esas alınmıştır. Her bir temaya ilişkin verilmiş olan yanıtlar tek dosyada toplanmış ve ayrı analiz edilmiştir. Analiz dâhilinde, kırılganlık düzeyine göre her mahallenin Covid-19 pandemisini mahalle düzeyinde nasil deneyimledikleri incelenmiştir. $\mathrm{Bu}$ deneyimler dikkate alınarak pandeminin yönetişimi hususundaki zorluklarının ve önerilerinin anlaşılması amaçlanmıştır. Farklı kırılganlık düzeyine sahip mahalleler arasında pandeminin etkileri açısından hem farklilıklara hem de benzerliklere odaklanılmış, pandemi öncesi yapı ve deneyimlerin, pandemi sırasındaki deneyimlere ve yaşanılan zorluklara nasıl etki ettikleri incelenmiştir.

\section{Bulguların Değerlendirilmesi}

\section{Mekâna Yansıyan Sosyal Kırılganlık}

Kendi mahalleleri hakkında bilgi vermeleri istendiğinde, muhtarlanın kullandıkları kelimelerin, mahallenin kırılganlık düzeyine göre farklılık gösterdiği göze çarpmaktadır. Mekâna yansıyan kırılganlığa bağlı olarak, bazı muhtarlar, mahallelerini yüksek ya da ortanın biraz üstü olarak tanımlarken, diğerleri orta, orta alt, yoksul, çok kozmopolit gibi ifadeler kullanmıslardır.

Sosyo-ekonomik düzeyi düştükçe, mahallenin, İstanbul'un genel dokusunun dışına çlktığına dair betimlemeler sunulmuştur. Türkiye'nin en büyük metropolü olan bu şehirde yaşasalar da mahalle sakinlerinin devam ettirdikleri geleneksel yaşam pratikleri ve ilişkiler ağırlık kazanmakta ve bu özellikler mahallenin karakterini de belirlemektedir. Orta-üst kırılganlık düzeyindeki bir mahallenin muhtarı, bu durumu "köy hayatını şehirde devam ettirmek" şeklinde tanımlarken, bahsi geçen köy hayatı pratiklerini aşağıdaki gibi anlatmıştır:

"İstanbul ama bizim burası İstanbul gibi değil; yani, hâlen kapılarda ateş yakıp ekmek yapan ablalara rastlayabilirsin. Yün serip yününü yıkayana rastlayabilme ihtimalin çok yüksek. Kapısında patlıcan 
közleme yapan, salça yapan insanlara rastlama şansımız var. Ama, görüldüğü zaman çok modern. Yani yaşantısı, ev düzenleri hep modern. Ama, kapı önü muhabbeti çok." (Orta-üst kırrlgan mahalle, erkek)

Kurılganlı̆̆1 orta-üst olan bir mahallenin muhtarı da kendi mahallesini "kenar mahalle" olarak tanımlamış ve bunu durumu da ülkenin daha çok Doğu ve Kuzeydoğusundan göçmüş olan ve eğitim seviyesi düşük mahalle sakinlerine bağlamıştır:

"Mahallemiz (ilçenin) kenar mahallelerinden birisi. Yani, merkeze biraz kenar mahalle, kenar semt, kenarı. Eğitim düzeyinin çok düşük olduğu, genelde Doğu, Güneydoğu Anadolu, sonra Karadeniz ağırlıklı bir mahalledeyiz." (Orta-üst kirllgan mahalle, erkek)

Buna karşılık, mahallenin sosyo-ekonomik düzeyi yükseldikçe ve kırılganlık düzeyi azaldıkça kültürel yapısı değişmekte, eğitim seviyesi ve maddi olanakları da yükselmektedir. Kırllganlı̆ğ daha düşük bir mahallenin muhtarı, kendi mahallesini "özel” bir konuma sahip görmekte ve mahallenin bu "özel” olmasinı da modern ve medeni mahalle sakinlerine bağlamaktadır:

"Bizim mahallemiz sosyo-ekonomik açıdan son derece yüksek düzeyde olan bir mahalle. Hem eğitim düzeyi de çok yüksektir. Maddi olanakları da yüksek bir mahalledir. Burası farklı yerdir, diyorum. Ülkenin İzmir'i gibi çok modern, medeni, insanlar birbirine saygill, anlayışl1, herkesin görüşlerine sayg1 duyan, özel bir mahalledir mahallem.” (Orta-alt kirilgan mahalle, kadın)

Bu "özel konum”a sahip mahallelerde sosyo-ekonomik düzeyin yüksek ve buna paralel bir şekilde eğitim düzeyinin de yüksek olduğu ifade edilmekte ve mahalle "bilinçli" bir mahalle olarak tasvir edilmektedir:

"Genelde emekliler vardır. Yarısı emekli, çocuk sayısı da az olur burada... (Bu ilçenin) bana soracak olursan en sakin, sessiz, diğer toplantılarda gördüğüm, en düzenli, en çok yeşil alana sahip mahallesiyiz. Sosyo-ekonomik seviyesi yüksek bir mahalleyiz... Mahalle sakinlerimin eğitim seviyesi yüksektir. Bu ilçede eğer bir şey yapmak istersen ilk benim mahalleden başlayabilirsin. Daha bilinçli bir mahalledir." (Orta-alt kırilgan mahalle, erkek)

Kirılganlı̆̆1 daha yüksek olan mahallelerde, muhtarlar kendi mahallelerindeki hanelerin genellikle fazla nüfusa sahip olduklarından bahsetmişlerdir. Bu yoğunluğu da yine Güneydoğu ve Doğu Anadolu bölgelerinden zamanında göç etmiş ailelerin çok çocuklu olmasıyla ilişkilendirmişlerdir. Örneğin, bir muhtar hane nüfusu yoğunluğuna vurgu yapmak için aşağıdaki çarpıcı örneği kullanmışırı:

"Şöyle bir şey anlatayım ben size; bundan aşağı yukarı 4-5 sene önce bir tane gencimiz vardı. Üniversiteye hazırlaniyordu. (...) Dedim 
'nereye gidiyorsun?' Dedi 'teyzemlere gidiyorum'. 'Niye, evde çalıssana oğlum' dedim. 'Evde, dedi, 16 kişiyiz'. 'Teyzengilde kaç kişisiniz?'. '13 kişiyiz' dedi. Yani ders çalsşmak için teyzesini seçti. Böyle bir mahalle yani tabii her ev bu şekilde değil. Ama ortalama en ufak bir ev 4 kişilik nüfusa sahip, en ufağı.” (Orta-üst kırılgan mahalle, erkek)

Kırılganlık azaldıkça mahallenin demografik yapısının değişim göstermeye başladığ1 ve yaşlı nüfusun ağırlık kazandığı görülmektedir. Artan yaşlı nüfusun talepleri değişmekte, yüksek eğitim ve sosyo-ekonomik düzeylerine rağmen yaşlillğa özel güçlüklerin ortaya çıkmasına neden olabilmektedir:

"Çok büyük bir bölümü emekli. Yani bu ilçenin genel şartları bizde de $\% 80$ emekli gibi diyebiliriz... Zor; sürekli zorlayıc1 hizmetler oluyor. Eğitim durumu yüksek, bu ilçede zaten genelde yüksek ve bizim mahalle de öyle." (Kirllgan olmayan mahalle, kadın)

\section{Mahalle Bazında Pandemi Tedbirlerine Uyumda Yaşananlar}

Görüşülen muhtarların üstüne en çok konuştukları ve sebepleri hakkında fikir yürüttükleri konu, mahalle sakinlerinin pandemi tedbirlerine uyum seviyelerine ilişkin olmuştur. Mahallelerin pandemi tedbirlerine uyum seviyelerinde, kırılganlık seviyesine göre farklılıklar olduğu görülmektedir. Ayrıca, hayat tarzı farklılıklarının -özellikle de geleneksel pratikler, apartman yaşamı ve çalışma biçimleri- tedbirlere uyum konusunda etkili olduğuna dair ipuçları sunulmuştur. Bilhassa yüksek kırılganlık seviyesine sahip mahallelerde pandemi yönetişimi zorlaşmakta, geleneksel ilişki ağları ağırlık kazanmakta, ayni ve nakdi gereksinimi olan hanelerin sayısı çoğalmaktadır. Dolayısıyla, bu mahallelerde pandemi öncesinde var olan kimi güçlükler pandemi ile birlikte daha da artmaktadır. Mahalle sakinlerinin eğitim düzeyi ve farkındalıklarının düşük ve kalabalık ailelerin pandemi tedbirlerine uymalarının zorlaşmasına bağlı olarak kuralsızlıklar artmakta ve bununla birlikte mahalle düzeyinde pandemiyi yönetmek zorlaşmaktadır.

Görüşmeler sırasında, kırılganlı̆ı yüksek mahallelerin muhtarları, henüz pandemi ve korona virüsü hakkında yeterli farkındalığın oluşmadığından ve kendi mahallelerindeki bireylerin, pandeminin önemini ve yarattığ1 tehlikeyi kavrayamadıklarından bahsetmişlerdir. Orta-üst kırılganlık seviyesine sahip bir mahallenin muhtarı, bu durumu, pandeminin etkili yönetişimi önündeki önemli bir engel olarak dile getirmiştir:

“Ama, dediğimiz gibi insanlarımız henüz bu şeyi daha kavramış değil.

Başlarına gelene kadar bu işi kavrayamıorlar. Görüyoruz bazen, diyoruz ki 'sen niye dışarıdasın, normalde senin karantinada olman gerek'... 'Ya bende bir şey yok ki' diyor. Ya sende olmadığını tamam biz de biliyoruz bir şey yok ama olma olasıllğı yüksek." (Orta-üst kırilgan mahalle, erkek) 
Mahalle sakinleri arasında farkındalığın eksik olmasından dolayı, pandemi tedbirlerine uymayan pratiklerin de yaygin olduğu ortaya çıkmaktadır. Orta-üst kırılganlık seviyesine sahip başka bir mahallenin muhtarı da farkındalık ile pandemi tedbirlerine uyum arasındaki ilişkiyi şöyle vurgulamıştır:

"İnsanlar da farkında değil yani şimdi buradan size göstersem, çay ocağının önü papatya gibi olmuş. Dizilmişler, yuvarlak mantar yapmışlar, o mantarın içinde geçiniyorlar, yaşıyorlar. Birbirleriyle sohbet ediyorlar. Farkında değiller hiçbir şeyin. Maske yok, sizde de yok, bende de yok gibi. Onlar da dişarıda beraberler, onlarda da yok. Hiçbir şeyin farkında değiller ama insanlar ölüyor.” (Orta-üst kırılgan mahalle, erkek)

İstanbul ilinin genelinde olduğu gibi, kendi mahallelerinde de bir kayıtsızlık ve ilgilenmeme durumu olduğuna dair tespitlerde bulunan ve bunu da kuralların eksikliğine bağlayan bazı muhtarlar olmuştur. Görüşmelerin Ekim-Kasım aylarında gerçekleştirildiği göz önünde bulundurulduğunda, muhtarların, normalleşme dönemi ve özellikle de yaz ayları boyunca gevşetilen tedbirlere ve bu tedbirleri gevşeten idari makamlara referans verildiği görülmektedir. Örneğin, kırilganlığ1 yüksek bir mahallenin muhtarı, kendi mahallesindeki tedbire uyum eksikliğini bireylerin eğitimi ya da önemsememesi ile ilişkilendirmek yerine, sistemle alakalı bir noktaya bağlamıştır:

"Bütün kahveler oyun oynatıyor kardeşim... (Bu ilçeye) değil, İstanbul geneline bakın, gidin gezin. Bütün kahvelerde oyun almış başını gidiyor. Bütün herkes yakın temas hâlinde (...) Hiç kimse ilgilenmiyor ki. Hiç kimse ilgilenmiyor. Ne emniyet ilgileniyor ne hekim... Ne kimse ilgileniyor; hiç kimse, hiç kimse ilgilenmiyor. Hiçbir şeye uyum yok. Niye? Kural yok. Kural yok, kural. Katı kural olacak. Bırakın siz o filmleri ya, çıksın devlet katı kural koysun.” (Orta-üst kı1ılgan mahalle, erkek)

Düşük ve yüksek kirılganlığa sahip mahallelerdeki uyum farklılıklarının, temelde eğitimle ilişkilendirildiği hemen göze çarpmaktadır. Yüksek kırılganlığa sahip mahallelerde düşük eğitim seviyesinin, pandemiye yönelik daha kaderci bir yaklaşıma sebebiyet verdiği üzerine aşağıdaki gibi ifadeler sunulmuştur:

"Eğitim seviyesi dediğim gibi çok düşük olduğu için birtakım şeyleri çok ciddiye almıyorlar. Neyi örneğin? Adamcağıza anlatıyorsun ya 'şu maskeni doğru dürüst tak, bak olay çok ciddi’. Her gün mahallemizde kayıplar var, (ilçemizde) kayıplar var. Ama adamcağız veya kadıncağız daha hâlâ olayın ciddiyetinin farkında değil. 'Kaderim yazmışsa,' diyor, 'Cenab-1 Allah yazmıssa ölürüm,' diyor. Her şeyi Allah’a bağlıyorlar. Tabii ki Allah, Cenab-1 Allah diyor ki 'şeyini tak, tedbirini al, gerisini bize birakın'. Ama, maalesef, adamlar da ona uymuyorlar." (Orta-üst kırilgan mahalle, erkek) 
Eğitim düzeyinin yüksek olduğu mahallelerde ise muhtarlar, tedbirlere uyum konusunda bir sıkıntı yaşamadıklarını belirtmişlerdir. Aksine, bu mahallelerde yüksek seviyedeki hassasiyeti simgeleyen bazı tepkiler aldığını belirten muhtarlar da olmuştur. Örneğin, kırılgan olmayan bir mahallenin muhtarı, kendi mahalle sakinlerinin tedbirlere uymayanları şikâyet ettiğinden bahsederken, kirilganlığ1 düşük bir mahallenin muhtarı ise sokağa çıkma yasaklarının kendi mahallesinde uygun görüldügünü vurgulamıştır:

"Ama, genel olarak insanlarımız kurallara uyan bir mahalle. Duyarlı insanlar o kadar çok ki 'işte bu işyerindeki şu tezgâhtar maskesini çenesinde tutuyor' diye şikâyetler bile geldi bize." (Kirilgan olmayan mahalle, erkek)

"Bizde daha iyiydi, yine söylüyorum. (Bu ilçe) genel olarak daha iyiydi. Çünkü, daha kültürlü olan semtlerde ve mahallelerde bu kurallara uymak daha kolay oluyor açıçası. Ben kendi mahallem için söylüyorum; sokağa çıkma yasaklarına gayet ciddi uyuldu. Sokakta kimseyi bulamazdınız falan. Hatta uygun da bulundu bu sokağa çıkma yasağı." (Orta-alt kırılgan mahalle, kadın)

Mahalle sakinlerinin pandemiye bakış açısına ya da eğitim seviyelerine vurgu yapan bu açıklamaların haricinde, mahalle yapısını belirleyen yakın akraba ilişkileri ve birlikte yaşama pratiklerine de değinerek, tedbirlere uyumda sıkıntı yaşadıklarını belirtenler, genellikle yüksek kırılganlık düzeyindeki mahallelerin muhtarları olmuştur. Bu muhtarlar, kendi mahallelerindeki bireylerin ya akrabalarıla aynı mahallede yaşadıklarını ve "sülale apartman"larında sürekli birbirlerinin evine girip çıktıklarını belirtmişler ya da komşuluk ilişkilerinin çok yakın olmasından dem vurmuşlardır. Aşağıdaki gibi ifadelerde, sokağa çıkmadan, aynı mekân içerisinde de virüsü yayma riskini artıran yakın akrabalık ilişkilerinin tedbirlere uyum önünde güçlük yarattığına değinilmiştir:

"Sokağa çıkma yasağına uyum düzeni çok güzeldi. Yani o da nasıl güzeldi; aynı aile binası 5 katın hepsi bir yere toplanıyor... Demin anlattım ya, zaten onlar düzeni bozuyorlar. Yani genelde aile düzeni olduğu için iç içe. Ya yan bina amcasının kızı ya üst bina ya arkadaki dayısının kızı. Böyle olunca birbirlerine zaten gidiyorlar da... Ama sokakta tabii görünmüyor.” (Orta-üst kirilgan mahalle, erkek)

Bu tür "sülale apartmanı" gibi durumları belli bir eğitim seviyesi, yaşam tarzına bağlayan düşük kırılganlık seviyesine sahip mahallelerin muhtarları, kendi mahallelerinde pandemi tedbirlerine uyumda sorun yaşamamalarını, bu yaşam pratiklerinin kendi mahallelerinde yer almamasına bağlamışlardır:

"Komşuculuk tabi var; ama, sülale apartmanı diyebileceğin bir apartman yok bende. O yüzden de bizim buralarda dairelerde yaşadık... Covidli olanlarımız var; ama böyle apartmanı karantinaya alacak kadar bir şey yaşamadım. Burada olmadı.” (Orta-alt kııılgan mahalle, erkek) 
Pandemi döneminde akrabalık ve komşuluk ilişkilerinin çok içli-dışlı olmasının yanında, geleneksel alışkanlıkların devam ettirilmesinin de yine kırılganlık seviyesi yüksek mahallelerde virüsün yayılmasının kontrol altında tutulmasını imkânsız hâle getirdiği görülmektedir. Ayrıca, muhtarlar, mahallelerindeki bireylerin bu tür pratiklerle virüsün yayılmasına ve tehlikeyi arttırmaya nasıl katkıda bulunduklarının pek farkında olmadıklarından ya da farkında olsalar bile yine de asker uğurlaması ve dügünlerini yapmaya devam etmek istemelerinden de yakınmışlardır:

"Askerî eğlenceler oluyor. Biz izin vermiyoruz; ama, gönül koyuyorlar. Bizim insanlarımız biliyorsunuz biraz çok duygusaldır. 'Bir oğlum var askere göndereceğim, eğlence yapmayacak mıyım?’ Yapma yani, şimdi oğlunu askere gönderirken hasta göndermek ister misin? Birisinin virüs kapmasının ister misin? 'Yok, ben dikkat ederim'. Ya ne kadar dikkat etmek isteseniz de mutlaka..." (Orta-üst kırllgan mahalle, erkek)

"Dernek Başkanı var; düğün yapmış oğluna. Nereden baksan salonda, bu pandeminin çok yoğun olduğu bir dönem... Nereden baksan '1000 kişi vardı' diyorlar. Salonda iğne atsan yere düşmez. Hatta belediye başkanı da kızmış." (Kırılgan mahalle, kadın)

Kırılganlığ1 daha düșük olan mahallelerin muhtarları ise, kendi mahallelerinde böyle "oryantal" bir kültürün yerleşik olmamasının, virüsün yayılmasını önlemek adına bir avantaj yarattığını belirtmişlerdir:

"Isşte sokak düğünü, ne bileyim işte evde düğün, evde kına, sünnet organizasyonları... Yani, böyle oryantal şeyler zaten yoktur (gülüyor). Normalde de yoktur, gene de olmadı. Kız alıp kız uğurlama seremonileri yoktur. Normalde de yoktu burada. Yani, ben hiç asker uğurlama görmedim.” (Orta-alt kırilgan mahalle, kadın)

Son olarak, kırılganlığı yüksek mahallelerin muhtarları, pandemi tedbirlerine uyumda, özellikle de fiziksel mesafenin korunmasında yaşanan sıkıntıları daha yapısal nedenlerle açıklamışlardır. Düşük gelirli mahallelerde işçi sınıfının yoğun olması ve buna bağlı olarak işe giderken metro ya da metrobüs gibi toplu taşıma araçlarının daha çok kullanılmasının tedbirlere uymayı güçleştirdiği görülmektedir. Aşağıdaki ifadelerden de anlaşılacağı üzere, kendi mahalle sakinleri maske takma gibi tedbirlere uyum sağlasa da diğer mahalle sakinleri ile bir araya geldikleri toplu taşıma araçlarında virüse maruz kalma risklerinin arttığına değinmişlerdir:

"İnsanlar uyuyor yani... Maske takma oranı yüzde 99 falan diyebiliriz. Ama, sosyal mesafe oranı biraz daha düşük o açıdan. Çünkü, şey yok hocam, yani bugün, burada, mesela bu mahalle çok vakaların olduğu yerlerden biriydi pandemi sürecinin Türkiye'ye gelmesiyle beraber. Bu mahalle ciddi anlamda proleter sınıfın olduğu, işçi sınıfının olduğu yer olduğu için hep otobüsleri kullanan bu mahallelilerdi. İşte, o 
metrobüsleri kullananlar (bu ilçedendi); ki biliyosunuz, toplu taşıma araçlarında bu bulaşın geçmesi daha bi hani daha mümkün, o yüzden." (Kirllgan mahalle, erkek)

"Şöyle, bizde biraz artş̧ oluyor bizim mahallemizde. Bunu ben şeye bağliyorum; metroya bağliyorum. (Bu mahalle) aktarma istasyonlu bir metro, yani geniş çaplı yaklaşık bir 3-5 mahalle bizden faydalanıyor o konuda. Ee tabi, metroda bir yoğunluk oluyor.” (Orta-üst kırllgan mahalle, erkek)

Buna karşılık, yine daha yapısal bir duruma işaret ederek kendi mahallesinde "apartman görevlisi" kültürünün devam etmesinin, pandemi tedbirlerine uyumu kolaylaştırdığını belirten, kırılganlık seviyesi düşük bir mahallenin muhtarı, bu tür olanakların olmadığı komşu mahallelerde farklı sıkıntıların yaşandığına dair gözlemlerini sunmuştur.

"Ama, Mart ayında bana sorsaydın \%90 uyuyor derdim. 65 yaş üstünü sokakta çok nadir görebilirsin. Yüzde doksan çıkmiyordu, evdeydi. Burada belediyenin çok desteği oldu. İnsanlar arabalarla alışverişler yapt1, evlere götürdü. Bir de benim mahallemde artılarımdan bir tanesi apartman görevlisi kültürü devam ediyor. Apartman görevlisi gitti; ihtiyaçlarını karşıladı falan. Şimdi, bu ihtiyaçları karşılamayan mahallelere baktığım zaman... Orada insanlar daha çok çıkmaya başladılar. Çünkü, neden? İhtiyaçlarını karşılayamıyorlardı.” (Orta-alt kirllgan mahalle, erkek)

\section{Muhtarların Pandemi Tedbirlerini Uygulamaya İlişkin Deneyimleri}

Mahalle sakinlerinin pandemi tedbirlerine uyum seviyesinin arkasinda yatan temel sebeplere dair açıklamalarının haricinde muhtarlar, bu tedbirleri uygulamada kendilerine düşen görevlerden ve yaptıklarından da bahsetmişlerdir. Bu dönemde, mahallenin ihtiyaçlarını nasıl karşıladıkları ya da ne gibi zorluklarla karşılaştıkları sorulduğunda, muhtarlar, çok farklı stratejiler geliştirdiklerine dair detaylı bilgi sunmuşlardır. Bu stratejiler: mahalle sakinlerinden ve gönüllülerden oluşan ekipler kurmak; ihtiyaç sahiplerine daha etkin bir şekilde ulaşabilmek adına ihtiyaç listeleri oluşturmak ve mahallî ağ sistemleri kurmak; yeri geldiğinde de hem kamu kuruluşlarılya ortaklaşa çalışmak hem de hayırseverlerden maddi destek talebinde bulunarak yardım dağıtmak şeklindedir. Tüm bu maddi ve maddi olmayan sorunlar ile pandemi yönetişiminde ortaya çıkan sıkıntılar karşısında, muhtarlar, kendi pozisyonlarının öneminin farkında; ancak, aynı zamanda yapabileceklerinin önüne birçok kısıtlama getirilmesinden de muzdarip görünmektedirler. Muhtarlardan bazıları, görev tanımlarının dar olması ve bütçelerinin olmamasından kaynaklanan sıkıntılar yaşadıklarından şikayet etmiş ve hem ekonomik yardımlarda hem de sosyal alanda yetki artırımı talebinde bulunmuştur. 
Muhtarlar, pandeminin yeni başladığı dönemde, alanda sadece kendilerinin olduğundan bahsederek konuya girmişlerdir. Pandemiden kaynaklanan korku ve şokla birlikte birçok mahalle sakini, en yakınlarındaki birim olan muhtarlıklara koşmuş ve bu durumda, aşağıdaki muhtarın da belirttiği üzere, bazıları, kendilerini yardım taleplerine tek başlarına cevap vermeye çalışır hâlde bulmuşlardır:

"Covid başladığı zaman bütün millet telaşlandı, eli ayağı karışmıştı. Bakın, onların gazını bizler, muhtarlar aldı, tamam mi? Bak, sokaklarda bir tane milletvekili görüyor musunuz? Vatandaşın dertleriyle ilgilenen yok. Bir tane belediye başkanı görüyor musunuz? Yok... Sadece muhtar burada. Biz gelene anlattık; gidene gida çeki verdik, kumanya çeki verdik. Onu verdik, bunu verdik; milletin gazını aldık... Kaymakamlığa gidiyorlar, valiye gidiyorlar, kimse görüşmedi bunlarla." (Orta-üst kirılgan mahalle, erkek)

Pandeminin ilk döneminde, en birincil yetkili olarak onları gören mahalle sakinlerinin talepleriyle daha sistematik bir şekilde ilgilenebilmek adına, mahalleliyi, özellikle de gençleri ve gönüllüleri örgütleyen kimi muhtarlar olmuştur. Bu dönemde, henüz vefa masaları kurulmamış ve kaymakamlık organize bir şekilde yardımları ulaştırmaya başlamamış olduğu için, muhtarların kurdukları bu ekipler çok önemli bir görev üstlenmiş görünmektedir:

"Dışarı ç1kma yasağ1 olduğunda ben hemen bir ekip kurdum gençlerden (...) Gençlerle bir organize olup bütün mahallenin alışverişini sağladık. Kimseyi dışarı çıkarmadan.” (Orta-alt kııılgan mahalle, erkek)

"Gönüllülük esasına dayalı, hemen burada birkaç gönüllü arkadaş yan yana geldik. Pandemi süresince 260 bin liralık yardım yaptık hiç devlet desteği olmadan. Yaklaşık 850-900 aileye biz yardımlarda bulunduk. Tabii bunlar önemli midir? Önemlidir... Ama, meselenin yoksulu doyurmak olmadığına inananlardanım. Yoksulluğun ortadan kaldırılması gerektiğine inanıyorum. Ama, bu lokal çözümlerde gerçek anlamda çok yetersiz kaldığımızı söyleyebilirim.” (Kırılgan mahalle, erkek)

Muhtarların pandemiden kaynaklanan ihtiyaçları daha etkin bir şekilde karşılayabilmede avantajlı oldukları bir unsur olarak ihtiyaç sahiplerinin kim olduğunu daha iyi biliyor olmaları göze çarpmaktadır. Yeni ihtiyaç sahiplerinin ortaya çıktığ pandemi döneminde ise yardımı nasıl ve nereden temin edeceklerini bilmeyen bazı kişilerin, ilk olarak muhtarlığa müracaat ettikleri görülmüştür. Aşağıdaki muhtarların ifadelerinden de anlaşılacağı üzere, bu yeni ihtiyaç sahipleri, kırılganlık seviyeleri birbirinden farklı mahallelerde benzer bir şekilde, muhtarların aracılı̆̆ıla merkezî ya da yerel yönetimler tarafindan dağıtılan yardımlara ulaşabilmişlerdir: 
"4 tane listemiz var bizim. 4 ayrı kategori... Birinci listemiz engelli kardeşlerimiz, azınlık da olsa. İkinci listemiz eşinden boşanan ve eşi vefat eden kardeşlerimiz; bir de en çok, yani, adamın teki çalışıyor... 4-5-6 çocuğu var; Evi kira, yetiştiremiyor... Bunlara da yardımc1 olduk bu vesileyle. Ama, bu Covid döneminde biliyorsunuz, işi olup da çalışamayanlar da oldu. İş yeri kapandı veya işine gidemedi. Bunların hepsine elimizden geldiği kadar, devlet olarak hem de muhtar olarak, kardeşleri bir abileri olarak yardımcı olmaya çalıştık." (Orta-üst kırılgan mahalle, erkek)

"Ben insanları ikiye ayırıyorum: Bir yardım almayı bilenler ve bilmeyenler var. Yardım almayı bilen kesim zaten y1llarca yardım almış; o biliyor nereye gideceğini... Kaymakamlı̆̆a şuraya buraya, prosedürleri bilir. Bir de yardım almayı bilmeyenler var. Onlara da biz muhtarlık olarak destek olmaya çalıştık." (Orta-alt kırılgan mahalle, erkek)

Kırılganlık seviyesi daha yüksek olan mahallelerin muhtarları, ihtiyaç sahiplerini hem daha hızlıca belirleyebilmek hem de yakından takip edebilmek için gerek mahalli ağlar kurmalanına bağlı olarak, gerekse de bir ekip olarak sistematik bir şekilde çalıştıklarından bahsetmiştir. Ayrıca, aşağıdaki muhtarların ifadeleri, çevrimiçi uygulamaların ve teknoloji kullanımının, sistematik pandemi yönetişimini kolaylaştırdığını göstermektedir:

"Bu konuda bizim (ilçe) kaymakamlı̆̆ımız Whatsapp hattı, (ilçe) Belediyesi Whatsapp hattı, Covid Whatsapp hatt1, Covid Kaymakamlık Whatsapp hattı, Covid-19 (ilçe) Belediyesi Whatsapp hatt1... Yani bir 5 tane hat kurduk; grup kurduk kendimize... Bir vatandaş bizi aradığı zaman biz aynı şöyle söylüyoruz: 'kimliğinizin resmini, adınız soyadınızı, telefon numaranızı ve ihtiyacınız olan gida gibi acil ihtiyacinız olan malzemelerin listesini tarafimıza atıorsunuz". (Orta-üst kır1lgan mahalle, erkek)

"Biz burada sabahladık çoğu kez. 3-4 tane arkadaşım geldi laptopları ile beraber. 6 bilgisayar çalıştık burada sabahlara kadar. Önce kayıt aldık, bizim bu muhtarlı̆̆ın önünde kuyruk oluştu bu sebepten dolayı. Biz hepsinin tek tek kayıtlarını aldık, bilgilerini aldık." (Orta-üst kır1lgan mahalle, erkek)

Muhtarlara, pandeminin ilk zamanlarındaki birincil rollerinden sonra, ilerleyen süreçte merkezî ve yerel yönetimlerin destek mekanizmalarını daha iyi organize ettikleri başka türlü görevler düşmüştür. Örneğin, aşağıdaki ifadelerde görüldüğü üzere, çoğu muhtar hem formel hem de enformel yardımları bir arada yönetmek durumunda kalmıştır:

“Biliyorsunuz devletimiz 'Vefa Sosyal Grubu' oluşturdu. Tabii muhtarlar olarak biz de o gruplardaydık. Ancak, şöyle bir şey var 
mahalle muhtarı olduğumuz için tabii ki hem vefa grubunda: kaymakamlığın sosyal vefa grubundan yardımc1 olduk, ekmek olmayanlara, hani sokağa çıkma yasağ döneminde ekmek ulaştırdık. İhtiyaçlarını ulaştırdık, erzak ulaştırdık. Ama, bizim muhtarlık olarak ayrıca yaptığımız, normalde tabii ki kaymakamlıkla birlikte çalıştık; ama, hayırseverler var, 'muhtarım biz size güveniyoruz bunları da gerçekten ihtiyacı olanlara verin' gibi.” (Orta-üst kırılgan mahalle, erkek)

Her ne kadar kurumsal ve formel yardım ve destekler sağlanıyor olsa da özellikle kırılganlığ daha yüksek olan mahallelerdeki artan talepleri karşılamaya yetmediğini veya yetişmediğine dair bilgilendirmede bulunan bazı muhtarlar olmuştur. Bu tip durumlarda, aşağıdaki ifadelerde de göze çarptığı üzere, muhtarlar kendi çevrelerinden, hayırseverlerden ve gönüllülerden kaynak toplamak durumunda kaldıklarından bahsetmişlerdir:

"Ondan sonra baktık ki bu olmayacak, kendim mahalle içerisinde bir çalışma yaptım. Eşten dosttan 3 gün içerisinde 44 bin lira para topladım. Güzel bir erzak yaptık. İnsanlara bunları dağıttık. Kiminin faturalarını... Farklı farklı ihtiyaçlara gittik. Yani biz insanlara kulak olduk, ses olduk, el ayak olduk." (Orta-üst kırllgan mahalle, erkek)

"Yani ben 200, evet 200 civarında koli buldum yine özel çevremden. Yani yaklaşı 30 bin lira da nakit yardımı yapabildim. Bu, direkt kendi hani şahsi çevremle yaptığım şeylerdi. Çünkü, yetersiz kaldı. Yani kurumlar, kurumlara yönlendiriyoruz; ama, bir Whatsapp hattı kuruldu... İşste, Vefa Hizmet hattı falan oluşturuldu. Şimdi oraya yağıyor yağmur gibi talepler. Yani sıraya alınıyor, işte prosedürden geçiriliyor falan... O arada, yani, çocuk mamasızlıktan, yaşlı besinsizlikten gidecek yani baya bir o dönemde (...) Biz hayırseverlerle ya da çevremizdeki iş adamlarıyla çözmeye çalıştık. Onlara gittik, rica ettik, yalvar yakar: 'Şöyle ailemiz var, şu kadar erzağa ihtiyac1 var... Bunun, ne bileyim, faturası ödenmemiş... Çocuğun işte üniversite bursu yok...’ gibi. Böyle kendi içimizde döngüyü çevirmeye sağladık.” (Kırılgan mahalle, kadın)

Görev tanımı ve yetki darlı̆g1 ile bütçelerinin olmaması, pandemi döneminde muhtarların yaşadıkları en büyük kısıtlama olarak ortaya çıkmaktadır. Kendilerini daha çok aracı konumda gören muhtarlar, yaptıklarından fazlasını yapmak istedikleri ya da kendilerinden bunun beklendiği durumlarda ise ya yukarıda belirtilen çeşitli stratejilere başvurmuşlar ya da mahalle sakinleriyle karşı karşıya kalmışlardır. Bu duruma sebebiyet veren merkezî yönetime serzenişte bulunan muhtarlar da olmuştur:

"Biz sadece devletle milletimiz arasında bir köprü vazifesi görüyoruz. İşte, kaymakamlığın Sosyal Yardımlaşma Kurumu'na, Vefa Grubu’na 
ya da belediyelere yönlendiriyoruz; ama, vatandaşın bu süreçte o bürokrasi işleri, ev incelemeleri, başvuru, bunlarla uğraşacak, o zamanı yok. (...) Bir de devleti direkt bizde görüyor, emin olun ki." (Kirılgan mahalle, kadin)

“Ama, muhtarın da elinde çok imkânı yoktur arkadaşım; bunu herkes öyle bilsin... Yani, ha o televizyonlarda anlatıyorlar ya 'muhtar her şeydir, gidin muhtara gidin,' de muhtarın bütçesi olmaz, muhtarın kasası olmaz. Aldığı 2200 lirayla halkına hizmet etmeye... Yani, köprü görevini yapıyor, devlet kurumlarıyla vatandaşın sıkıntılarını buluşturma noktasında. Hızlandırma adına yalnızca bir elçi oluyor; köprü görevini yapıyor. Ona da duyarlı muhtar varsa yapar; ya yoksa da gider oturur sabah sekiz buçuktan akşam dört buçuk beşe kadar bekler... Açar, kapatır.” (Orta-üst kırılgan mahalle, erkek)

Muhtarlar hem maddi hem de sosyal anlamda yetkilerinin arttırlmas1 taleplerinin, temel olarak ihtiyaç sahiplerine daha hızlı ve etkin bir şekilde ulaşabilmek adına olduğunu belirtmişlerdir. Orta-üst kırılgan bir mahallenin muhtarı, kendilerine biçilen aracı rolünün, salgın yönetişiminin etkinliğini azalttı̆̆ını şu örnekle net bir şekilde ortaya koymuştur:

"En basiti sana söyleyeyim; az önce aradı beni bir tanesi: 'Abi, Covid'im, ailem de Covid, dışarı çıkamıyorum'. Ben bunu yazacağım kaymakamlığa, o yazacak... Ya böyle saçma bir şey olur mu? Muhtarsam, devleti temsil ediyorsam, bana diyorsun ki 'git Covidli adamı kontrol et'. Ya öyle boş kepçeden atmayacaksın ya, getireceksin bana diyeceksin ki: 'muhtarım, sana iki bin liralık BìM çeki zimmet ediyorum. Verdiğin her hastanın adını soyadını, kimlik numarasını bana bildireceksin ama bu sende kalacak.' Biz zaten kendimizi feda etmişiz muhtarlar olarak. Biz n'apacağız, gideceğiz adamın ziline basacağı: 'kardeşim al şu çeki' ya da 'al şu gıda kolini', 'kolin geldi burada, in aşağı al."' (Orta-üst kırılgan mahalle, erkek)

Tüm bu maddi ya da ayni destek sunmada yaşanan sıkıntılar ve geliştirilen stratejilere ek olarak, yalnız yaşayan yaşlı nüfusu daha yüksek olan kırılganlığı düşük mahallelerde, bu gruplara çeşitli hizmetler götürdügünü anlatan muhtarlar olmuştur. Bu muhtarlar, özellikle salgı̀n döneminde 65 yaş üstüne uygulanan sokağa çıkma yasakları ile birlikte, bu yaş grubunun kendine has ihtiyaçlarının doğduğundan ve bu ihtiyaçları karşılamada özellikle ilk dönemlerde kendilerine çok fazla iş düştüğünden bahsetmişlerdir:

"Her ne kadar devlet Vefa Grupları diye bir şeyler yapmaya çalışsa da... Yani, işte hükümetimiz, ama, yeterli olmuyor tabii çok büyük nüfuslardan bahsediyoruz. Şunu fark ettik, belli yaş üstü insanlarımızın kart kullanmadığını gördük. Yani, emekli maaşlarını çekemez hâle geldiler; çünkü, çoluğuna çocuğuna verecek bir kartı 
yok. Yani, onu işte... Herhalde bir güvensizlik var; bankalara karşı mı diyelim... Genel bir durum mu... Kendisi o maaşını alıyor; bunları fark ettik. Çok yaşı insanlarımızın kart kullanmadığını, zaten internet bankacılığı hiç bilmediklerini... Böyle sorunlarla karşılaştık." (Kırılgan olmayan mahalle, erkek)

Pandemi döneminde, mahalledeki yaşlı bireylerin en temel sorununun maaşlarını çekmede yaşadıkları sıkıntılar ile ilgili olduğu vurgulanmıştır. Bir muhtar, bu sorunu gidermede kendilerine görev düştüğünü şu şekilde ifade etmiştir:

"Tek başına yaşıyor yardımcısıyla; hanımefendi ya da beyefendi, sokağa çıkamıyor. Para ihtiyacı var; çocuklar yurtdışında... Bankaya da gidemiyor. Benim banka hesabıma çoğu çocuk para gönderiyor. Ben onları çekiyorum, makbuzuyla birlikte eve götürüyorum. Banka muhtarı gibi çalıştı̆ıı oldu." (Orta-alt kırıllgan mahalle, erkek).

Son olarak, pandemi yönetişiminde yaşadıkları sıkıntıların arasında, normalleşme dönemiyle birlikte yetkilerindeki azalma ve dolayısıyla mahalle sakinlerinin onlara yaklaşımlarında bir değişim olduğunu da belirtmişlerdir. Özellikle, kırılganlığı yüksek mahallelerin muhtarları, tedbirlere uyum sağlamayan mahalle sakinlerini uyarmaları durumunda tehditlerle ve olumsuz tepkilerle karşılaştıklarını anlatmışlardır:

"Şimdi muhtar olarak karşılaştı̆̆ımız en çok zorluk şu var: Bize elimizi taşın altına konulması söyleniyor. Tamam; biz elimizi taşın altına koyalım... Tahmininiz, belki haberlerde izlemişsinizdir haberlerde, bir polis memuru bay-bayan fark etmez, 'maskeni tak' dediğinde neredeyse polis memurunu döveceklerdi. Şimdi burada da biz aynı şeyle karşılaşıyoruz. 'Hanımefendi; maskeni tak' dediğinde, 'Sana ne! benim kocam var benim oğlum var' veya 'beyefendi; maskeni tak' dediğimde 'sana ne kardeşim oluyorsam ben oluyorum'. Bu tepkilerle biz de karşlaşıyoruz." (Orta-üst kırılgan mahalle, erkek)

"Şimdi adam 3500 lira ceza yiyecek. Kendi hatasını görmüyor. Covidlisin; ama, evinde durmamışsın. Denetlemeyi muhtar yapiyor. Direkt diyor ki: 'denetlemeyi kim yapiyor? Muhtar.' 'Tamam demek ki muhtar, sen beni ihbar ettin. Senin yüzünden gittim ben üç gün yurtlarda galdım' ya da 'ben senin yüzünden 3600 lira ceza yedim. Sen göreceksin."” (Kırılgan mahalle, kadın)

\section{Tartışma ve Sonuç}

$\mathrm{Bu}$ makalede, farklı sosyal kırılganlı düzeyine sahip mahallelerin Covid-19 pandemisini nasıl deneyimledikleri, muhtarların gözünden değerlendirilmiştir. Muhtarların paylaşımları, mahallenin sosyal kırılganlık düzeylerinin, pandemiyi deneyimleme biçimleri üzerinde etkisi olduğunu ve muhtarların pandemiyi yönetmeye yönelik çabaları ile mahallenin sosyal kırılganlık düzeyinin ilişkili 
olduğunu göstermiştir. Mahallenin sosyal kırılganlık düzeyi arttıkça, mahalle kalabalıklaşmakta, dışlayıcı gücü azalmakta ve kırılgan gruplar artmaktadır. Sosyal kırılganlık arttıkça, haneler kalabalıklaşmakta, hanelerde eğitim düzeyi azalmakta, kişisel araç sahipliği düşmekte ve ilişkili olarak toplu taşıma kullanım zorunluluğu artmaktadır. Ekonomik boyutun yanı sıra, artan sosyal kırılganlık düzeyi geleneksel yaşam pratiklerini çoğaltmakta, farkındalığı azaltmakta ve kaderci düşünmeyi arttırmaktadır. Buna bağlı olarak mahalledeki hanelerin gereksinimleri artmakta ve muhtarlar artan gereksinimlere yanıt vermeye çalışmaktadırlar. Böylece, muhtarlığı işlevsel hâle getirmeye yönelik geliştirilen stratejileri çeşitlenmekte ve muhtarlar daha fazla sorumluluk üstelenmektedirler. Ayrıca, sosyal kırllganlık düzeyi artan mahallelerde bulunan haneler için en kolay erișilebilen merci, muhtarlık olmaktadır. Dolaysiyla, pandemi döneminde mahallenin artan gereksinimleri ve mahalle sakinlerinin beklentileri birleşerek muhtarları daha sorumlu hâle getirmektedir. Kendilerini artan sorumluluklarla karşı karşıya bulan muhtarlar, yetkilerinin azlığını, bütçelerinin olmamasını dert edinmekte ve daha etkin ve etkili olabilmeleri için muhtarllğın değişmesini ve daha fazla idari ve mali imkânlara sahip olmayı talep etmeye başlamaktadırlar.

Mahallelerin kırılganlık düzeyi azaldıkça sosyo-ekonomik düzey ve eğitim düzeyi de artmakta ve mahalle sakinlerinin muhtardan beklentileri azalmaktadır. Öte yandan, mahallenin sosyo-ekonomik düzeyi artmakta iken yaşlı nüfus yoğunluğunun arttığ1 görülmektedir. Bu durum, ekonomik beklentileri azaltmakta, ancak, ekonomik olmayan gereksinimleri artırmaktadır. Ekonomik olmayan gereksinimleri karşılayan muhtarlar açısından mahalle düzeyinde pandemiyi yönetmek kolaylaşmıştır. Aynı zamanda, yaşlı nüfusun beklentilerini karşılamak muhtarları işlevsel kılmış ve kendilerini etkin ve etkili hissetmelerine yol açmışır.

Tüzel kişiliğe sahip olmadıkları için kendilerine ait personeli ve bütçesi olmayan, dolayısıyla da özerklikten yoksun olan mahalle muhtarlı̆̆ının kamu yönetimi sistemi içerisinde de yasal açıdan önemli bir yere sahip olmadığ1 belirtilmektedir (Önver, 2020). Ancak, pandemi deneyiminin gösterdiği üzere, böyle kriz süreçlerinde, mahalle muhtarlığının bütçe ve personelin olmayışı, pandeminin etkin yönetişimi açısından önemli bir sorun olarak görülmektedir. Öte yandan, muhtar deneyimleri, bu eksikliklerin bazı muhtarları hareketsiz kıldığını ve muhtarların bu durumu hareketsiz olmalarını haklılaştırmak için kullandıklarını göstermektedir. Özellikle, kır1lgan mahallelerin muhtarları, mahalle sakinlerince birincil sorumlu kılınmış ve tüm yetersizliklere rağmen daha etkili olmayı istemiş ve bunun için bazı formel ve enformel stratejiler geliştirmişlerdir. $\mathrm{Bu}$ yapabilirliklerinden hareketle, muhtarlık kurumunun güçlendirilmesini de talep etmişlerdir. Bu tür kriz anlarında, mahalleyi en çok bilen, değişimleri ve talepleri yakından takip edebilen muhtarlar, daha güçlü bir muhtarlık kurumunun imkânlarına sahip olmayı istemekte ve bunu hak ettiklerini de düşünmektedirler.

Köklü ve Gül'ün (2017) mahalle muhtarllğının dönüşümü ve muhtarlık algısı üzerine Isparta ilinde yapmış oldukları saha çalışmasının sonuçlarına göre 
muhtarların kendilerine dair algıları iki gruba ayrılmaktadır: Muhtarların yarısı kendilerini "lider" diğer yarısı da "temsilci" olarak tanımlamaktadır. Bu çalışmanın sonuçları da bu bulguyu desteklemektedir: Yapabilirliği daha yüksek olan ve çaba sarf eden muhtarların, kendilerini mahalleden sorumlu kimse olarak gördükleri, buna karşılık, bazı muhtarların ise kendilerine daha fazla sorumluluk yüklemedikleri görülmüştür.

Mahalleyi tanımlamanın güç olduğu ve mahallenin hem sosyolojik hem de idari açıdan değiştiği ve dönüştüğü görülmektedir. Bu kapsamda, farklı sosyal kırılganlık düzeyine sahip mahallelerin sosyo-demografik yapılarının da farklı olduğu ve buna bağlı olarak standart ve tek bir pandemi yönetiminin de mümkün olamayacağ1 ortaya çıkmıștır. Mahallenin sakinlerinin kimler olduğu, sosyoekonomik düzeyleri, eğitim düzeyleri, kendi aralarındaki tanışıklık düzeyleri, ne kadar süredir İstanbul'da yaşadıkları ve geleneksel yaşam pratiklerinin tümünün pandemi deneyimini şekillendirdiği, dolayısıyla da muhtarların değişen bu sosyolojik yapıya göre tavır aldıkları görülmektedir.

Bu çalışmanın bazı sınırlılıkları söz konusudur: Covid-19 pandemisi boyunca virüsün yayılma riski ve pandeminin sosyal hayata etkisinin çeşitli demografik gruplar için farklı biçimlerde deneyimlendiği gözlemlenmiştir. Bilhassa, yaşlılar ve kadınların pandemi deneyimleri hem haberlere hem de akademik çalışmalara konu olmuştur. Bu çalışmada da yaşlıların bir sosyal grup olarak yoğunlaştı̆̆ı mahallelerin sosyal kırılganlık düzeylerine paralel olarak pandemiyi farklı deneyimledikleri ortaya konulmuştur. Pandeminin ilk dönemlerinde yaşçllk ve yaşlılara yönelik ayrımc1 hareketler gündemi meşgul etmiş olsa bile, muhtarlar, kendi mahallelerindeki deneyimleri anlatırken bu tür pratiklere değinmemişlerdir. Bunun bir sebebi, bu çalışmanın odak noktasını yaşlılık değil sosyal kırılganlığın oluşturmasıdır. Nitekim muhtarların paylaşımlarında, kadınların pandemi deneyimlerinin erkeklerinkinden ne şekilde farklılaştığı da yer almamıştır. Bu çalışmanın parçası olduğu projenin nicel veri kısmında bireylerin toplumsal cinsiyet ve yaş değişkenlerine göre pandemiyi deneyimleme biçimlerine odaklanılmıs, ancak, muhtarlarla yapılan görüşmelerde bu konulara ayrıntılı girilmemiştir.

$\mathrm{Bu}$ çalışmanın bulguları, gelecekte olabilecek kriz yönetimlerine mahalle düzeyinde yaklaşmanın, muhtarların yapabilirliklerinin artırılmasının katkı sağlayıcı olduğunu, standart ve tek-tipçi pandemi yönetişimi yerine, mahalle sosyolojisini dikkate alan yönetişim planlarının hazırlanmasının önemli olacağına işaret etmektedir. Son olarak, muhtarların çevrimiçi uygulamaları ve teknolojiyi kullanabilme becerilerinin, pandemi yönetişiminde etkisinin olduğu görülmüş; bu alanı etkin kullanabilen muhtarların hareket kabiliyetlerinin artmakta olduğu anlaşılmışır. Bu veriden hareketle, mahalle muhtarlarının teknolojik yetkinliklerinin arttırılmasının, gelecekte yaşanabilecek afetlerin daha iyi yönetilmesine katkı sağlayabileceği düşünülmüştür. 


\section{KAYNAKÇA}

Akman, Ç. (2018). "Mahalle Yönetimi ile ilgili Yeni bir Yasal Düzenleme gerekli mi?: Isparta ili özelinde bir araştırma." Akademik Araştırmalar ve Çalışmalar Dergisi (AKAD), 10(19), 516-534.

Akyıldız, Ş. (2020). Covid-19 İş Gücü Piyasasını Nasıl Etkiledi? TEPAV. https://www.tepav.org.tr/upload/files/1592555617-

5.COVID 19 Isgucu Piyasasini_Nasil Etkiledi.pdf (10.04.2021)

Altunöz, H. B. (2020). Salginda Mubtarlar Devlet ile Vatandas Arasinda Köprü Oldu. Anadolu Ajans1, https://www.aa.com.tr/tr/turkiye/salginda-muhtarlardevlet-ile-vatandas-arasinda-kopru-oldu-/2075963 (25.05.2021)

Arrkboğa, E. (1999). "Yerel Yönetim açısından Mahalle Muhtarlığına bir Bakış." Çă̆daş Yerel Yönetimler Dergisi, 8(3), 103-125.

Ayataç, H. Ve Turan, S. (2020). "Karantina ve Kamu Sağlığı Bağlamında Dayanıklı Mahalle.” Şehir ve Düşünce, 16, 32-42.

Bankoff, G. (2002). Cultures of Disasters: Society and Natural Hazards in the Philippines. Routledge, London.

Bulut, Y. (2001). "Mahalle Muhtarlı̆̆ı Üzerine bir Araştırma." Çağdaş Yerel Yönetimler Dergisi, 10(3), 32-51.

Bulut, Y. Ve Akın, S. (2020). "Katılımcı Demokrasi Açısından Mahalle Yönetiminin Önemi." Mahalle Odaklı Katılım, 45-53.

Bulut, Y. Ve Kara, M. (2011). "Mahalle Muhtarlarının Kent Ve Mahalle Güvenliğine İlişkin Yaklaşımları: Antakya Örneği.” Mustafa Kemal Üniversitesi Sosyal Bilimler Enstitüsü Dergisi, 8(15), 1-28.

Bulut, C. (2020). "Kent Kimliğinin oluşumunda Mahallenin etkisi: Balat, Selçuk ve Musa mahalleleri örnekleri." Pamukkale Üniversitesi Sosyal Bilimleri Enstitüsü Yayımlanmamış Yüksek Lisans Tezi.

Cannon, T., Twigg, J. Ve Rowell, J. (2003). "Social Vulnerability, Sustainable Livelihoods and Disasters." Report to DFID Conflict and Humanitarian Assistance Department (CHAD) and Sustainable Livelihoods Support Office, 93.

Craddock, S. (2000). "Disease, Social Identity and Risk: Rethinking the Geography of AIDS." Transactions of the Institute of British Geographers, 25(2), 153168.

Cutter, S. L., (1996). "Vulnerability to Environmental Hazards." Progress in Human Geography, 20(4), 529-39.

Cutter, S. L., Ve Finch, C. (2008). "Temporal and Spatial Changes in Social Vulnerability to Natural Hazards." Proceedings of the National Academy of Sciences, 105(7), 2301-2306.

Çakı, F. Ve Özbayram, G. G. (2020). "Muhtarlar ve Topluluk-Temelli Afet Yönetişimi." Adam Academy Journal of Social Sciences/Adam Akademi Sosyal Bilimler Dergisi, 10(2), 447-485. 
Çaman, Ö. K. Ve Karabey, S. (2020). Bir Pandeminin Su Yürüne Çıkardlklar: Sağlkta Eşitsiz̨likler ve Politikalara Yansimalar. TESEV Değerlendirme Notlanı. https://www.tesev.org.tr/wp-

content/uploads/rapor_bir_pandeminin_su_yuzune_cikardiklari_saglikta_esit sizlikler_ve politikalara yansimalari.pdf (13.05.2021)

de Moraes Silva, D. R. Ve Mont'Alverne, C. (2020). "Identifying Impacts of Covid-

19 Pandemic on Vulnerable Populations: a Mixed-methods Approach." Survey Research Methods, 14(2), 141-145.

Eren, İ. Ö. (2017). Mahalle. Yeni bir paradigma mümkün mü? Tuti Kitap.

Eryılmaz, B. (1988). “Türkiye'de Köy ve Mahalle Muhtarlıklarının Ortaya Çıkışı ve Gelişimi." Türk İdare Dergisi, 378, 465-475.

Estrela, F. M., Soares, C. F. S., Cruz, M. A. D., Silva, A. F. D., Santos, J. R. L., Moreira, T. M. D. O., ... Ve Silva, M. G. (2020). "Covid-19 Pandemic: Reflecting Vulnerabilities In The Light Of Gender, Race And Class." Ciencia \& Saude Coletiva, 25, 3431-3436.

Göküş, M. Ve Alptürker, H. (2016). “6360 Sayllı Yasa ile Köy Yönetiminden Mahalle

Yönetimine Geçiş Sonrası Etkin Hizmet Sunumuna İlişkin Muhtarların

Görüşü: Silifke Köyleri Örneği.” Selçuk Üniversitesi Sosyal ve Teknik Araştırmalar Dergisi, (11), 67-86.

Güneş, Y. (2009). "Mahalle Yönetimi." Türk İdare Dergisi, 465, 113-131.

Holzmann, R. Ve Jørgensen, S. (2001). "Social Risk Management: A New Conceptual Framework for Social Protection, and Beyond." International Tax and Public Finance, 8(4), 529-556.

Kalipeni, E. (2000). "Health and Disease in Southern Africa: A Comparative and

Vulnerability Perspective." Social Science and Medicine, 50(7), 965-983.

Kavruk, H. (2018). Mahalle Yerleşimi ve Yönetimi. Nobel Akademik Yayıncllik. Keyder, Ç. (2009). İstanbul: Küresel ile Yerel Arasında, Sungur Savran (Çev.). İstanbul: Metis Yayinclik.

Köklü, T. E. Ve Gül, H. (2017). “Türkiye’de Mahalle Muhtarliğının Dönüşümü ve Yeni Muhtarlık Algisı.” Van Yüzüncü Yıl Üniversitesi SBE Dergisi, Kamu Yönetimi Özel Sayısı (KAYFOR), 14, 719-733.

McLafferty, S. (2010). "Placing Pandemics: Geographical Dimensions of Vulnerability and Spread." Eurasian Geography and Economics, 51(2), 143-161.

Önver, M. Ş. (2020). “Türkiye'de Mahalle Yönetimi.” Uluslararası Anadolu Sosyal Bilimler Dergisi, 4(3), 37-60.

Özkan Erdoğan, Ş. (2016). "Mahalle ve Türkiye'de Mahalle Muhtarllğı." Ankara Üniversitesi Sosyal Bilimler Enstitüsü Yayımlanmamış Yüksek Lisans Tezi.

Palabiyık, H. Ve Atak, Ş. (2002). “Türkiye'de Mahalle Yönetimi”, Parlak, B. Ve Özgür, H. (der.) Avrupa Birliği ile Bütünleşme Sürecinde Türkiye’de Yerel Yönetimler içinde. Alfa Yayınları, 331-371. 
Ro, C. (2020). Coronavirus: Why some racial groups are more vulnerable. https://www.bbc.com/future/article/20200420-coronavirus-why-someracial-groups-are-more-vulnerable (25.05.2021)

Sands, P., El Turabi, A., Saynisch, P. A. Ve Dzau, V. J. (2016). "Assessment Of Economic Vulnerability To Infectious Disease Crises." The Lancet, 388(10058), 2443-2448.

Sayin, Ö. Ve Bozkurt, V. (2020). "The Pros And Cons Of Living In A Global City During A Pandemic: The Covid-19 Experience Of Istanbul', The Covid-19 Pandemic And Its Economic, Social, And Political Impacts içinde, 137150.

Smith, J. A. Ve Judd, J. (2020). “Covid-19: Vulnerability And The Power Of Privilege In A Pandemic.” Health Promotion Journal Of Australia, 31(2), 158.

Stephenson, N., Davis, M., Flowers, P., Macgregor, C. Ve Waller, E. (2014). "Mobilising "Vulnerability" In The Public Health Response To Pandemic Influenza." Social Science \& Medicine, 102, 10-17.

Şahin, Y. Ve Asarkaya, S. (2019). "Mahalle Muhtarlığı Kurumunun Tarihi Gelişimi”. Aksaray Üniversitesi İktisadi ve İdari Bilimler Fakültesi Dergisi, 11(3), 23-32.

Yalçındă̆, S. (1998). "Yerel Demokrasinin Örgütlenmesi ve Yerinden Yönetiminin Geliştirilmesi Açısından Muhtarlık Kurumu.” Çağdaş Yerel Yönetimler Dergisi, 7(3), 37-56. 


\section{EK 1. Mahalle Muhtarı - Yarı-Yapılandırılmı̧̧ Görüşme Soruları}

- Öncelikle sizi biraz taniyabilir miyim?

- Biraz mahallenizi anlatır misınız?

- $\quad$ Bu mahallede yakın geçmişte deprem, sel, yangin gibi bir afet oldu mu?

- Mahallenizde yaşayanların kolayca erişebileceği sağlık merkezi, hastane var mı?

- Mahalleniz Covid-19 salgınını nasıl yaşadı/yaşıyor?

- $\quad$ Mahalle düzeyinde mahallenizin aldığı/almadığ1 destek ve hizmetleri dikkate alarak yerel yönetimler ile merkezi hükümetin destek ve hizmetlerini nasıl değerlendirirsiniz?

- Covid-19 salgını bittiğinde mahallenin ne tür sorunlarla karşılaşabileceğini düşünmektesiniz?

- Gelecekte böylesi bir salgin/afet durumu olma ihtimalini dikkate alınarak ne/neler önermek istersiniz? 
